\title{
DENTAL CARIES IN CHILDREN THAT PARTICIPATED IN A DENTAL PROGRAM PROVIDING MOTHER AND CHILD CARE*
}

\author{
CÁRIE DENTÁRIA EM CRIANÇAS QUE FREQUENTARAM UM PROGRAMA \\ ODONTOLÓGICO DE ATENÇÃO MATERNO-INFANTIL
}

Lúcia de Fátima Almeida de Deus MOURA, Marcoeli Silva de MOURA², Orlando Ayrton de TOLEDO

\begin{abstract}
1- DDS, MSc, PhD, Graduate student (Doctor's degree), University of Brasília, Assistant Professor, Department of Pathology and Dental Clinic at Federal University of Piaui.

2- DDS, MSc, PhD, Assistant Professor, Department of Pathology and Dental Clinic at Federal University of Piaui.

3- DDS, MSc, PhD, Associate Professor at the University of Brasilia.

* This study is an integral part of the doctorate thesis to be defended in the Post Graduation Program in Health Sciences at the University of Brasilia - ASSESSMENT OF THE ORAL HEALTH LEVEL OF CHILDREN ATTENDING A DENTAL PROGRAM FOR MOTHERS AND CHILDREN.
\end{abstract}

Correponding address: Lúcia de Fátima Almeida de Deus MOURA - Rua Angélica, 1650 - Bairro de Fátima - Cep.: 64048-161 - Teresina - PI e-mail: mouraiso@uol.com.br - Telephones: (086) 32333050 and 32325928.

Received: October 18, 2004 - Modification: April 1, 2005 - Accepted: May 12, 2005

\begin{abstract}
Ther

he main goal of this study was to evaluate the prevalence of caries in children that participate in a dental program attending mothers and children in Teresina, Piauí, Brazil. A selection was made of 343 children of both genders, from 3 to 6 years of age. The mothers answered questionnaires and children were examined at the Infant Dental Clinic of the Federal University of Piauí. The epidemiological index dmft was applied and active white spot lesions were included. The SPSS for Windows program, version 11.1 was used and non-parametric tests carried out (Friedman and Kruskal-Wallis). An alpha error of 5\% (0.05) was considered for the null hypothesis of false rejection, with a confidence interval of $95 \%$. The results showed that $57.5 \%$ (197) of the children were breast-fed for a period longer than 12 months. The mean dmft index and percentages of caries-free children at the age of 3 was 1.86 (58.82\%); at 4 years of age 1.94 (57.60\%); at 5 years of age 1.98 (56.86\%) and at 6 years of age 2.42 (42.55\%). The decay component (d) was prevalent at all ages. When active white spot lesions were added to the dmft index, there was an increase of $7.2 \%$ for children who had caries activity and/or previous caries experience and $2.61 \%$ for those with dmft equal to zero. The daily consumption of fermentable carbohydrates and free demand breast-feeding were factors increasing caries activity. Dental follow-up after the program and the number of daily brushings were shown to be factors providing protection against caries. Based on the results, the authors were able to conclude that the program caused a positive impact on caries disease control, as the number of dental appointments kept influenced the dmft index values in a statistically significant manner.

Uniterms: Dental caries; Epidemiology; Health promotion; Oral health.
\end{abstract}

\begin{abstract}
RESUMO
O objetivo do presente estudo foi avaliar o impacto apresentado por um programa de atenção materno-infantill na prevalência de cárie de crianças participantes. Foram selecionadas 343 crianças, de ambos os gêneros, nas idades de 3 a 6 anos. As mães responderam a questionários e as crianças foram examinadas em consultórios da clínica odontológica infantil da Universidade Federal do Piauí (UFPI). Foi aplicado o índice epidemiológico ceod com acréscimo de lesões de manchas brancas ativas. Os dados foram analisados pelo programa SPSS para Windows, versão 11,1 e realizados os testes não paramétricos (Friedman e Kruskal-Wallis). Considerou-se um erro alfa de 5\% (0,05) para hipótese nula de falsa rejeição, com um intervalo de confiança de 95\%. Os resultados mostraram que 57,5\% (197) das crianças foram amamentadas ao seio por um tempo superior a 12 meses. A média do índice ceo-d e percentuais de crianças livres de cárie para a idade de 3 anos foi de 1,86 (58,82\%); aos 4 anos, de 1,94 (57,60\%); aos 5 anos, de 1,98 (56,86\%) e aos 6 anos de 2,42 (42,55\%). O fator cariado (c) foi prevalente em todas as idades. Quando foram acrescentadas ao índice ceo-d lesões de manchas brancas ativas, houve um aumento de 7,2\% para crianças com atividade e/ou experiência anterior de cárie e de 1,72\% para aquelas com ceod igual a zero. O consumo diário de carboidratos fermentáveis e a amamentação em livre demanda se apresentaram como fatores incrementais da atividade de cárie. O acompanhamento odontológico posterior ao programa e o número de escovações diárias demonstraram ser fatores de proteção contra a instalação da doença cárie. Baseados nos resultados, os autores puderam concluir que o programa provocou impacto positivo no controle da doença cárie, uma vez que o número de consultas freqüentadas influenciou nos valores do índice ceod de maneira estatisticamente significativa.

Unitermos: Cárie dentária; Epidemiologia; Promoção de saúde; Saúde Bucal.
\end{abstract}




\section{INTRODUCTION}

Dental caries is a multifactorial disease related to people's lifestyle; therefore, control and prevention are intimately linked to changes in daily habits and attitudes, which should be started early on within the family circle. The desired changes are associated with alterations of dietary and oral hygiene habits, as well as the use of fluorides.

Within the perspective approached, a group of professors from the Federal University of Piauí implemented a university extension project in April 1997, the Preventive Program for Pregnant Mothers and Babies, whose goals are to recover and maintain oral health in pregnant women and children aged zero to 36 months of age (Moura, et al. ${ }^{11}$, 2001).

During attendance provided by the Preventive Program for Pregnant Mothers and Babies, the function of health promoter is delegated to the mothers, as it is through them that the transmitted information will be disseminated and put into practice in the family and/or collective circle (Figure 1). The project does not isolate the proposed conducts and/ or make them vertical, but puts their interdisciplinary nature into practice, which is allowed by the facilities where the program is developed - the Social Perinatology Institute of Piauí, a "child-friendly” hospital - health outpatient section, where there is interaction of various health science specialties for treating pregnant women and children.

Epidemiological surveys present the prevalence of caries disease and an indication of the need for restorative treatment, but are not capable of identifying the dynamics of the process, because they are unable to differentiate active and inactive lesions. The epidemiological index most used for primary teeth is the $\mathrm{dmft}^{2}$, which represents the mean of decayed primary teeth (d), missing or indicated for extraction (m) and filled (f) per child.

The purpose of this study was to determine the impact of a program attending mothers and children on the prevalence of caries in the children involved, through the epidemiological index dmft and family, social and behavioral determinants.

\section{MATERIALAND METHOD}

The project was sent to the Ethics Committee of the Federal University of Piauí (UFPI) for appreciation and

FIGURE 1- Attendance Protocol of the Preventive Program for Pregnant Mothers and Babies.

Federal University of Piauí, 2005

\section{Educational Lectures - Guidance to Pregnant Women}

1. About the care to be taken with regarding the prevention of prevalent oral diseases;

2. The importance of dental care during pregnancy;

3. The importance of breast feeding

4. The harmful potential of non-nutritional sucking habits.

Initial Clinical Attendance of the Child - before the first teeth erupt

Examining the child:

Evaluating the oral cavity;

Guidance about oral hygiene; Diaper dampened in filtered water. Should be timed to coincide with that of body hygiene; The importance of breast feeding;

Guidance about the potential disturbances that may cause non-nutritional sucking habits;

Guidance about the time sequence in which primary teeth erupt.

\section{Preventive Maintenance Attendance - after eruption of teeth}

Erupted Anterior Teeth:

Guidance about diet (rational use of sugar) and harmful sucking habits;

Guidance about the importance of controlling night feeding;

Oral hygiene should be done using a piece of diaper or gauze, with a small amount of fluoridated toothpaste added;

Topical fluoride application

Quarterly preventive maintenance.

Erupted Molars:

Guidance about diet (rational use of sugar) and harmful sucking habits;

Beginning with tooth brushing. A child's tooth brush and a small amount of toothpaste is used;

Topical fluoride application

Quarterly preventive maintenance.

Children that present with active white spot lesions

Return for four consecutive weeks to motivate the family about toothbrushing and dietary control;

Topical fluoride gel application

Quarterly preventive maintenance.

Children that present decayed teeth, are victims of dental traumatisms, or have reached the limit-age of $\mathbf{3}$ years.

Are referred for attendance at the UFPI children's clinic. 
assessment and was approved in October 2003 (Report 004/ 2003).

The parents signed a free informed consent term, in compliance with the National Health Council Resolution 196/ 96, that issues research guidelines and rules involving human beings.

The sample was determined by utilization of the clinical records of 5,132 children who had attended the PPGB but were no longer eligible, because they had reached the age limit of 36 months. Of these records, the ones of children that had entered the program before their first teeth erupted (2,689 records) were selected, according to the number of consultations they received at the PPGB. Random draws were made of the selected records, and letters were sent to the parents of 1,801 children.

The study was conducted with 343 children of both genders, 174 females and 169 males from 3 to 6 years of age, living at the metropolitan region of Teresina - PI, Brazil. The exams were performed of December 2003, January, February and July 2004.

Data collection was structured in two stages: application of questionnaires on background followed by clinical exam of the children. The questionnaires were drawn up with questions in the form of closed alternatives, approaching some socio-economic variables, including family income stated in terms of the number of minimum wages comprising it. The questionnaire structure was based on research in the literature and adapted to the objectives of the study. The questionnaire was pre-tested with 40 mothers, with the object of introducing the necessary adjustments for improving understanding of the subject dealt with.

\section{Examining the children}

The children were examined at the infant clinic at the Federal University of Piauí. Before the exams started, they were instructed about the health/disease process and methods of preventing and/or controlling oral diseases. The children were submitted to prophylaxis, using a tooth brush and tooth paste; when necessary, the procedure was complemented with rubber cups and abrasive paste. The exams were done with the aid of an oral mirror and blunt tipped exploratory probe, illuminated by a reflector and in a dry field.

The children were examined by the author of the study and an assistant who took notes, both previously trained and calibrated, without knowing the number of times that the child had participated in the Preventive Program for Pregnant Mothers and Babies.

The epidemiological index dmft was applied, which enables the quantitative expression of caries prevalence in primary teeth. When it was noted that teeth had been extracted early, the mothers were asked what had led to their loss; when it was found that abrasion had been caused by dental caries, these teeth became part of the index. Active white spot lesions were included, in order to identify the dynamics of the caries process. No radiographs were taken.

Intraexaminer error was assessed by the kappa calculation, whose agreement was considered to be excellent $(\mathrm{k}=0.9)$. To validate the diagnostic criteria, the exams were repeated in $10 \%$ of the assessed sample ( 45 children).

The SPSS for Windows program, version 11.1 was used to analyze the data. Non-parametric tests (Friedman and Kruskal-Wallis) were carried out to check the statistical association among the studied variables. An alpha error of $5 \%(0.05)$ was considered for the null hypothesis of false rejection, with a confidence interval of $95 \%$.

\section{RESULTS}

Of the group of children examined, 55.7\% (191) were shown to be free of caries disease $(\mathrm{dmft}=0)$. After stratifying these observations $(\mathrm{dmft}=0)$ by age, the results obtained were as follows: $58.82 \%(60)$ at 3 years; $57.60 \%(53)$ at 4 years; $56.86 \%(58)$ at 5 years and $42.55 \%(20)$ at 6 years (Table 1).

On analyzing Table 2, one finds a significant negative correlation between the number of consultations scheduled in the Preventive Program for Pregnant Mothers and Babies

TABLE 1- Mean of dmft index components, according to age and confidence interval of $95 \%$. Federal University of Piauí, 2005

\begin{tabular}{|c|c|c|c|c|c|c|c|c|c|c|}
\hline \multirow[b]{2}{*}{ Age } & \multirow[b]{2}{*}{$\mathbf{N}$} & \multicolumn{2}{|c|}{$\mathrm{dmft}=0$} & \multirow{2}{*}{$\begin{array}{l}\text { Mean } \\
\text { dmft }\end{array}$} & \multirow[t]{2}{*}{ d } & \multirow[t]{2}{*}{ m } & \multirow[t]{2}{*}{$f$} & \multirow{2}{*}{$\begin{array}{l}\text { dmft + } \\
W^{* *}\end{array}$} & \multirow[t]{2}{*}{ LL*** } & \multirow[t]{2}{*}{$U L^{* * * *}$} \\
\hline & & $\mathbf{N}$ & $\%^{*}$ & & & & & & & \\
\hline 3 & 102 & 60 & 58.82 & 1.86 & 1.50 & 0.09 & 0.26 & 2.05 & 01 & 12 \\
\hline 4 & 92 & 53 & 57.60 & 1.94 & 1.45 & 0.21 & 0.28 & 2.11 & 01 & 14 \\
\hline 5 & 102 & 58 & 56.86 & 1.98 & 1.50 & 0.23 & 0.25 & 2.13 & 01 & 13 \\
\hline 6 & 47 & 20 & 42.55 & 2.42 & 1.32 & 0.54 & 0.56 & 2.47 & 01 & 11 \\
\hline Total & 343 & 191 & - & 2.05 & 1.44 & 0.27 & 0.34 & 2.19 & 01 & 14 \\
\hline
\end{tabular}

\footnotetext{
* \% in relation to the number of children examined according to age group.

$\star *$ WS $=$ white spots

*** LL = lower limit

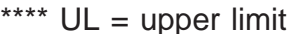


and the dmft index values $(\mathrm{r}=-0.25, \mathrm{t}=4.80, \mathrm{p}<0.01)$.

The regression analysis of the data allows to establish that, under the conditions in which the study was carried out, the children would present a dmft index $=0$ if the number of times they attended the Preventive Program for Pregnant Mothers and Babies were 10 times (Figure 2).

The age at which the child began to have a mixed diet did not show a statistically significant result in relation to the development of dental caries disease.

Within the Preventive Program for Pregnant Mothers and Babies attendance protocol, one of the objectives was the continuity of clinical and educational/preventive follow up of children at the Federal University of Piauí infant clinic after the 3-year age limit. Of the 122 (35.56\%) children that remained in the program up to this stage, $78.7 \%$ (96) were referred to the Federal University of Piauí for attendance and of these, only $33.6 \%$ (41) sought the proposed attendance. The low index of seeking attendance at the Federal University of Piauí infant dental clinic was justified by the mothers as being due to lack of time, difficulty of getting to the Federal University of Piauí and because they had been unable to make the desired appointments.

Higher levels of caries were noticed in children who did not seek dental attendance after being discharged from the program. The analysis of this variable presented statistical significance $\left(c^{2}=17.57\right.$ and $\left.\mathrm{p}<0.01\right)$.

From analyzing Figure 3, one finds a significant negative correlation between the variables analyzed $(r=-0.19, t=3.63$, $\mathrm{p}<0.01$ ), a fact that led to the conclusion that the higher the family income, the lower the dmft index values found.

\section{DISCUSSION}

The social condition is considered to be an important determinant of the level of a community's oral health. Piauí is one of Brazilian states with the lowest per capita income, a fact that exposes the population to social deprivations and risk factors. The quality of public water supply fluoridation in the city of Teresina is deficient and lacks the installation of the hetero-control system by Sanitary Surveillance Agency ${ }^{3}$.

The Ministry of Health disclosed information about the prevalence of dental caries in Brazil (SB Brasil 2003), and the ages studied for primary teeth were from zero to 36 months and at 5 years of age. At the age of 5 , the rate of children with carious teeth reaches almost $60 \%$ in the Northeast region and the dmft index for the related age was $3.21^{4}$; parallel to this, the data found in this study for the age referred to, was 1.98, a fact which, even considering the methodological

TABLE 2- dmft Index values and the number of consultations provided in a Preventive Program for Pregnant Mothers and Babies. Federal University of Piauí, 2005

\begin{tabular}{|c|c|c|c|c|c|c|c|c|c|c|}
\hline \multirow{3}{*}{$\mathrm{dmft}$} & \multicolumn{8}{|c|}{$\mathrm{N}^{\circ}$ of Consultations } & \multirow{2}{*}{\multicolumn{2}{|c|}{ Total }} \\
\hline & \multicolumn{2}{|c|}{1} & \multicolumn{2}{|c|}{$2-3$} & \multicolumn{2}{|c|}{$4-5$} & \multicolumn{2}{|c|}{$\geq 6$} & & \\
\hline & $\mathbf{N}$ & $\%$ & $\mathbf{N}$ & $\%$ & $\mathbf{N}$ & $\%$ & $\mathbf{N}$ & $\%$ & $\mathbf{N}$ & $\%$ \\
\hline 0 & 43 & 22.5 & 60 & 31.4 & 34 & 17.8 & 54 & 28.3 & 191 & 100.0 \\
\hline 1 to 3 & 18 & 24.6 & 23 & 31.6 & 15 & 20.5 & 17 & 23.3 & 73 & 100.0 \\
\hline 4 to 6 & 17 & 39.5 & 12 & 27.9 & 10 & 23.3 & 04 & 9.3 & 43 & 100.0 \\
\hline 7 to 9 & 06 & 35.3 & 07 & 41.1 & 02 & 11.8 & 02 & 11.8 & 17 & 100.0 \\
\hline$\geq 10$ & 09 & 47.4 & 09 & 47.4 & 01 & 5.2 & 00 & 0.0 & 19 & 100.0 \\
\hline
\end{tabular}

TABLE 3- Breast-feeding time and dmft index. Federal University of Piauí, 2005

\begin{tabular}{|c|c|c|c|c|c|c|c|c|c|c|c|}
\hline \multirow{3}{*}{$\mathrm{dmft}$} & \multicolumn{11}{|c|}{ Breast-feeding time (months) } \\
\hline & \multirow{2}{*}{$\begin{array}{l}\mathrm{N}^{\circ} \text {. of } \\
\text { Children }\end{array}$} & \multicolumn{2}{|c|}{$\begin{array}{l}\text { Did not } \\
\text { breast-feed }\end{array}$} & \multicolumn{2}{|c|}{1 to 3} & \multicolumn{2}{|c|}{4 to 6} & \multicolumn{2}{|c|}{7 to 12} & \multicolumn{2}{|c|}{ Over 12} \\
\hline & & $\mathbf{N}$ & $\%$ & $\mathbf{N}$ & $\%$ & $\mathbf{N}$ & $\%$ & $\mathbf{N}$ & $\%$ & $\mathbf{N}$ & $\%$ \\
\hline Zero & 191 & 08 & 4.2 & 16 & 8.4 & 19 & 9.9 & 39 & 20.5 & 109 & 57.0 \\
\hline 1 a 3 & 73 & 05 & 6.8 & 01 & 1.3 & 12 & 16.5 & 17 & 23.4 & 38 & 52.0 \\
\hline 4 a 6 & 43 & 01 & 2.3 & 02 & 4.6 & 07 & 16.3 & 09 & 20.9 & 24 & 55.9 \\
\hline 7 a 9 & 17 & 00 & 0.0 & 01 & 5.8 & 00 & 0.0 & 04 & 23.6 & 12 & 70.6 \\
\hline$\geq 10$ & 19 & 01 & 5.3 & 00 & 0.0 & 03 & 15.8 & 01 & 5.2 & 14 & 73.7 \\
\hline Total & 343 & 15 & 4.4 & 20 & 5.8 & 41 & 12.0 & 70 & 20.4 & 197 & 57.4 \\
\hline
\end{tabular}


differences used and the various environmental conditions, proves the impact that Preventive Program for Pregnant Mothers and Babies caused on the studied population.

To allow evaluation of caries disease activity in children in various Brazilian regions, some studies pertinent to the subject were selected and summarized in Figure 4. The standard used for selecting the articles was based on the index used, age group and the geographic region where the study was conducted. It becomes difficult to determine comparative parameters between the results herein presented and those referred to in the literature and/or SB 2003, because of the different methodologies used. In the project SB 2003, the children were examined at home and/or day-care centers, while in the present study they were examined under favorable consulting-room conditions and submitted to previous dental prophylaxis. The facts dealt with have suggested that the conditions under which the oral exam is carried out have significant influence on determining the epidemiological indexes that determine the prevalence of caries disease.

The FDI/WHO ${ }^{5}$ (2000), for the year 2000 proposed that $50 \%$ of the children at 5 years of age should be caries-free, a goal that was accomplished by the evaluated program, even though it had been noted that in the case of children aged 6 years, only $42.5 \%$ had no caries experience. The prevalence of the decayed component (d), observed in Table 1 , suggests the need for including children at pre-school age in public dental services, which have historically given priority to children of school-going age ${ }^{6}$.

The increase in the prevalence of dental caries in older children (6 years of age) could probably be attributed to the greater independence acquired with regard to tooth brushing and choosing their own diet. This suggests that further studies should be drawn up, capable of scientifically proving the hypotheses put forward.

When active white spot lesions were added to the cariesfree children group $(\mathrm{dmft}=0)$, there was an increase of $2.61 \%$ in the index (Table 1 ). In children with caries activity and/or previous caries experience $\left(\mathrm{dmft}^{3} 1\right)$, the white spot lesions caused an impact of $7.2 \%$ on the dmft index (positive

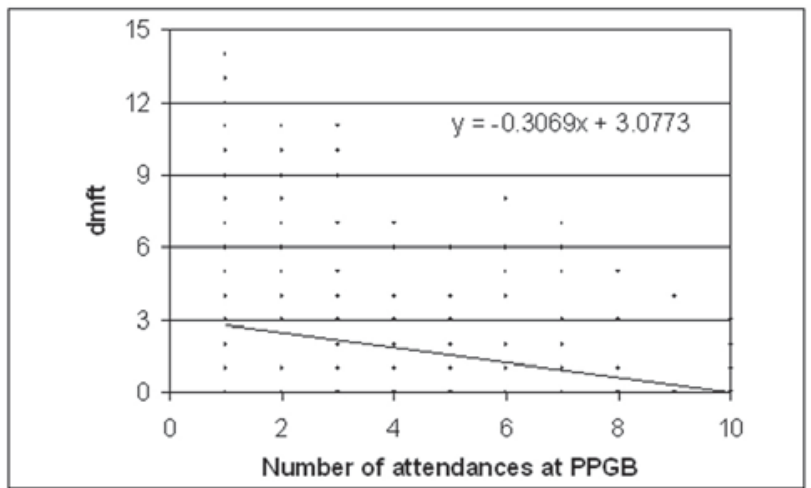

FIGURE 2- Projection of the number of appointments kept and dmf index. If the number of attendances by the Preventive Program for Pregnant Mothers and Babies were 10 times, the dmf index would be zero. Federal University of Piauí, 2005 correlation $\mathrm{p}<0.01)$.

Ismail $^{7}$ (2004) draws attention to the importance of diagnosis and treatment of initial carious lesions, emphasizing the impact that restorative decisions have on a nation's oral health levels.

$<$ Figure 4 $>$

The question of self-care was approached by evaluation of the frequency of daily brushing, monitoring of the process by adults and by the level of child's cooperation. In the set, these variables did not present statistically significant results with regard to the development of caries disease, with the exception of the number of daily brushings, which presented a significant negative correlation $(\mathrm{r}=0.13, \mathrm{t}=$ 2.42, $\mathrm{p}<0.02$ ). This could be attributed to the use of fluoridated dentifrices ${ }^{15}$.

The results found in this study corroborate the data reported by Tomita, et $\mathrm{al}^{16}$ (1996). They do, however, disagree with those presented by Rong, et $\mathrm{al}^{17}$ (2003); which prove the efficacy of supervised brushing after 2 years of evaluating a preventive dentistry program developed with pre-school aged children living in China.

The highest dmft index values (polarization of the disease) were found in children that were breast-fed for longer than 6 months (Table 3). This proof points to a relevant question about the risk/benefit that free demand breast-feeding may represent to children's oral health after the eruption of the first teeth. This leads to opening debates focused on the cariogenic potential and/or cariogenicity of mother's milk, because of being a controversial and inconclusive subject in the pertinent literature.

Control of the breast-feeding time is a sensitive point hardly touched on in the literature, as a result of the unquestionable benefits presented by breast-feeding and the fact that mothers who work outside the home only have time to breast-feed their children at night, a period in which the prolactine rates are higher.

The 55th World Health Organization (WHO) World Assembly $^{18}$ (2002) recommended that exclusive breast feeding should be kept on free demand up to the nursing

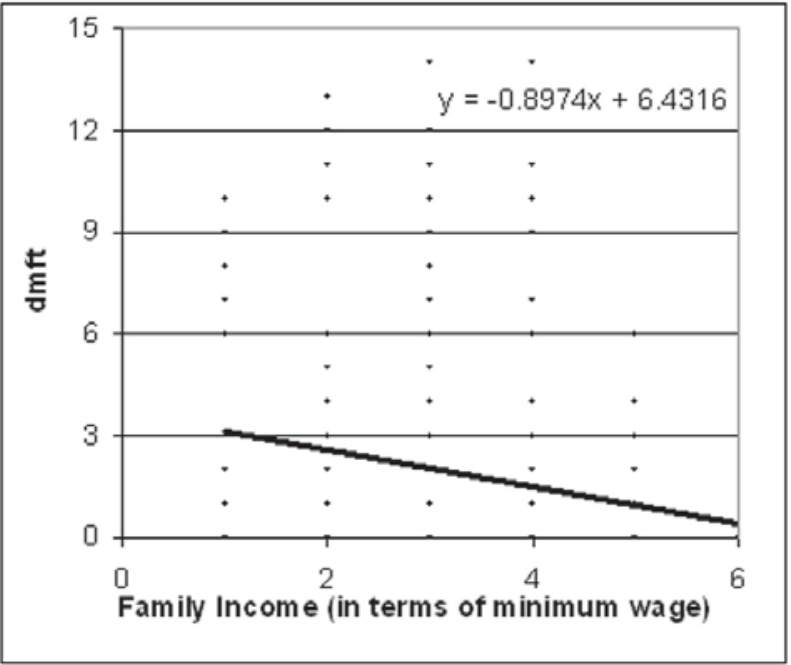

FIGURE 3- Family income and dmft index value. Federal University of Piauí, 2005 
infant's sixth month of life. The guidance proposed by the WHO is in agreement with that developed in the Preventive Program for Pregnant Mothers and Babies.

With regard to the daily ingestion of fermentable carbohydrates, the results were statistically significant $\left(\mathrm{c}^{2}\right.$ $=20.93$ e $\mathrm{p}<0.01$ ). Although the great majority of mothers (93.6\%) know about the potential harm that repeated sugar consumption may do to oral health, $42.9 \%$ of children were shown to consume it with a high daily frequency and 52.77\% with moderate frequency. The approach to using sugar in a rational way is also a delicate matter to discuss, as consumption is modulated by biological, emotional, social, economic and environmental factors. The results found corroborate those presented by Honkala, et al. ${ }^{19}$ (1984),

TABLE 4- The Chi-square test $\left(\chi^{2}\right)$ and the $p$ values for behavioral variables according to the presence or absence of dental caries, Federal University of Piauí, 2005

\begin{tabular}{|c|c|c|c|c|c|c|c|}
\hline \multirow[t]{2}{*}{ Variable } & \multirow[t]{2}{*}{ Categories } & \multicolumn{2}{|c|}{$\begin{array}{l}\text { Presence of } \\
\text { caries }\end{array}$} & \multicolumn{2}{|c|}{$\begin{array}{l}\text { Absence of } \\
\text { caries }\end{array}$} & \multirow[t]{2}{*}{$\chi^{2}$} & \multirow[t]{2}{*}{$p$} \\
\hline & & $\mathbf{N}$ & $\%$ & $\mathbf{N}$ & $\%$ & & \\
\hline Brushing frequency & 1 & 27 & 45.7 & 32 & 54.3 & & \\
\hline \multirow[t]{2}{*}{ (times/day) } & 2 & 70 & 46.0 & 82 & 54.0 & 0.61 & $n s^{*}$ \\
\hline & $\geq 3$ & 55 & 41.6 & 77 & 58.4 & & \\
\hline Brush before going & yes & 103 & 43.8 & 132 & 56.2 & 0.03 & ns \\
\hline to sleep & no & 48 & 44.8 & 59 & 55.2 & & \\
\hline Who performs & Child & 23 & 42.6 & 31 & 57.4 & & \\
\hline \multirow[t]{2}{*}{ Oral Hygiene } & Child/Adult & 70 & 46.0 & 82 & 54.0 & 0.34 & ns \\
\hline & Adult & 59 & 43.0 & 78 & 57.0 & & \\
\hline \multirow[t]{3}{*}{ Accepts brushing } & Yes & 115 & 44.0 & 146 & 56.0 & & \\
\hline & No & 26 & 52.0 & 24 & 48.0 & 2.48 & 0.29 \\
\hline & More or Less & 11 & 34.4 & 21 & 65.6 & & \\
\hline Daily Sugar & Always & 83 & 56.5 & 64 & 43.5 & & \\
\hline \multirow[t]{2}{*}{ Consumption } & Sometimes & 64 & 80.0 & 16 & 20.0 & 20.93 & $<0.01$ \\
\hline & Never & 04 & 26.6 & 11 & 73.4 & & \\
\hline Age at which started & 2 to 5 & 36 & 44.4 & 45 & 55.6 & & \\
\hline ingesting other foods & 6 to 9 & 89 & 43.8 & 114 & 56.2 & 1.66 & ns \\
\hline \multirow[t]{3}{*}{ (months) } & Over 9 & 16 & 42.1 & 22 & 57.9 & & \\
\hline & Do not & & & & & & \\
\hline & remember & 03 & 75.0 & 01 & 25.0 & & \\
\hline Attendance, after & Did seek & 106 & 69.73 & 91 & 47.64 & & \\
\hline \multicolumn{7}{|l|}{ from PPGB } & $<0.01$ \\
\hline Dental care after & 1 to 6 & 65 & 51.2 & 62 & 48.8 & & \\
\hline discharge from & 6 to 12 & 29 & 39.7 & 44 & 60.3 & 4.05 & 0.04 \\
\hline PPGB (months) & Over 12 & 57 & 40.1 & 85 & 59.9 & & \\
\hline
\end{tabular}

${ }^{*}$ ns $=$ not statistically significant 
Tomita, et al. ${ }^{21}$ (1999), Fraiz and Walter ${ }^{20}(2001)$.

The preference for sugar is highly influenced by increased exposure to cariogenic foods and the greater availability of options, both associated with urbanization, which has a series of implications on the development of public policies for promoting a healthy diet and guidance to parents concerning children's diets ${ }^{1}$.

When evaluating the frequency of consultations at the Preventive Program for Pregnant Mothers and Babies (Table 2), it was found that children that participated in the program six or more times presented lower caries prevalence, which can be proved by statistically significant data $\left(c^{2}=4.05\right.$ e p $=0.04$ ). When a projection was made, increasing the number of consultations to 10, the dmft index fell to zero (Figure 2). This provides scientific backing for justifying the children's three-monthly visits to the Preventive Program for Pregnant Mothers and Babies. That is when clinical evaluations and preventive maintenance procedures are carried out and educational/preventive actions are reinforced and individualized through dialogue with the family members.
Based on the results presented, it was possible to conclude that, the greater the frequency of participating in the Preventive Program for Pregnant Mothers and Babies, the lower was the index of carious teeth observed in the assisted children. This confirms the importance of educational health guidance, which should be backed up in the conception of teaching learning, so that the information is memorized. Thus, independence is gained concerning the self-care of one's health.

\section{ACKNOWLEDGEMENT}

Thanks to Prof. Dr. Luís Evaldo de Moura Pádua Professor at the Federal University of Piauí - for the guidance

\section{CONCLUSION}

\begin{tabular}{|c|c|c|c|c|c|}
\hline Authors / Year & $\begin{array}{l}\text { Children's } \\
\text { ages (years) }\end{array}$ & Place & $\begin{array}{l}\text { dmft Index } \\
\text { (years) }\end{array}$ & $\begin{array}{l}\text { Prevalent } \\
\text { Component (\%) }\end{array}$ & $\begin{array}{l}\text { Caries-free: } \\
\text { age } \%\end{array}$ \\
\hline This Study & $3-6$ & Teresina - PI & $\begin{array}{l}\text { 3: } 1.86 \\
\text { 4: } 1.94 \\
\text { 5: } 1.98 \\
\text { 6: } 2.42\end{array}$ & decay & $\begin{array}{l}3: 58.82 \\
4: 57.60 \\
5: 56.86 \\
6: 42.55\end{array}$ \\
\hline $\begin{array}{l}\text { Freire MC } \\
\text { et } \mathrm{al}^{8}(1996)\end{array}$ & $0-6$ & Goiânia - GO & $\begin{array}{l}\text { 3: } 1.14 \\
\text { 4: } 2.18 \\
\text { 5: } 3.18 \\
\text { 6: } 3.94\end{array}$ & $\begin{array}{l}\text { decay }(d)-\text { public } \\
\text { Filled }(f)-\text { private }\end{array}$ & $\begin{array}{l}\text { 3: } 69.9 \\
\text { 4: } 49.5 \\
\text { 5: } 36.1 \\
\text { 6: } 29.4\end{array}$ \\
\hline $\begin{array}{l}\text { Saliba NA } \\
\text { et al. }{ }^{9}(1998)\end{array}$ & $3-6$ & Araçatuba - SP & $\begin{array}{l}\text { 3: } 0.80 \\
\text { 4: } 1.53 \\
\text { 5: } 2.28 \\
\text { 6: } 2.27\end{array}$ & decay & $\begin{array}{l}\text { 3: } 70.00 \\
\text { 4: } 57.79 \\
\text { 5: } 42.63 \\
\text { 6: } 40.40\end{array}$ \\
\hline $\begin{array}{l}\text { Cypriano S } \\
\text { et al. }{ }^{10}(1999)\end{array}$ & 5 e 6 & Piracicaba - SP & $\begin{array}{l}\text { 5: } 2.64 \\
\text { 6: } 3.07\end{array}$ & decay 45.3 & $\begin{array}{l}\text { 5: } 44.3 \\
\text { 6: } 38.5\end{array}$ \\
\hline $\begin{array}{l}\text { Leite ICG and } \\
\text { Ribeiro RA } \\
\text { ( 2000) }\end{array}$ & $2-6$ & Juiz de Fora (MG) & $\begin{array}{l}\text { 3: } 1.4 \\
\text { 4: } 1.9 \\
\text { 5: } 2.4 \\
\text { 6: } 2.9\end{array}$ & decay & $\begin{array}{l}\text { 3: } 64.7 \\
\text { 4: } 45.7 \\
\text { 5: } 44.0 \\
\text { 6: } 40.0\end{array}$ \\
\hline $\begin{array}{l}\text { Pinto, } \text { LMC }^{9} \\
(2000)\end{array}$ & 5 & Londrina - PR & - & - & 71.1 \\
\hline $\begin{array}{l}\text { Feitosa S and } \\
\text { Colares V }{ }^{13}(2004)\end{array}$ & 4 & Recife - PE & 4: 2.06 & decay -47.0 & - \\
\hline $\begin{array}{l}\text { Ueda EMO } \\
\text { et al. }{ }^{14}(2004)\end{array}$ & 3 e 5 & Cambira - PR & $\begin{array}{l}\text { 3: } 2.10 \\
\text { 5: } 3.51\end{array}$ & decay -50.86 & $\begin{array}{l}\text { 3: } 68.50 \\
\text { 5: } 31.10\end{array}$ \\
\hline
\end{tabular}

FIGURE 4- Prevalence of dental caries in primary teeth in various Brazilian regions 


\section{REFERENCES}

1- Moura LFAD, Lira DMMP, Moura MS, Barros, SSLV, Lopes TSP, Leopoldino VD, Moura MDM. Apresentação do programa preventivo para gestantes e bebês. J Bras Odontopediatr Odontol Bebê. 2001;4(17):10-4.

2- Gruebbel AO. A measurement of dental caries prevalence and treatment service for deciduous teeth. J Dent Res. 1944;23(3):1638 .

3- Silva JS, Moura MS, Simplício AHM, Cury JA. Avaliação da água de abastecimento público de Teresina - PI. Pesqui Odontol Bras. 2002;16(Suppl):40. (Anais da 17ª Reunião Anual da SBPqO).

4- Projeto SB Brasil 2003: condições de saúde bucal da população brasileira 2002-2003: resultados principais / Ministério da Saúde, Secretaria de Atenção à Saúde. Departamento de Atenção Básica. Brasília: Ministério da Saúde, 2004. Available in: <http:www.saúde.gov br/bucal>.

5- FDI (Fédération Dentaire Internationale)/WHO (World Health Organization), 1982. Global goals for oral healthy by the year 2000 . Int Dent J. 1982;32:74-7.

6- Pinto VG. Saúde bucal coletiva. 4 ed. São Paulo: Ed. Santos; 2000.

7- Ismail A. Diagnostic levels in dental public health planning. Caries Res. 2004;38(3):199-203.

8- Freire MC; Melo RB; Almeida e Silva S. Dental caries prevalence in relation to socioeconomic status of nursey school children in Goiânia-GO, Brazil. Community Dent Oral Epidemiol. 1996;24(5):357-61.

9- Saliba NA, Orenha ES, Nakam L, Meneghim MC, Momias SA. Prevalência de cárie dentária em crianças de 3 a 6 anos de idade, do município de Araçatuba-SP. Rev Odontol UNESP. 1998;27(1):20713.

10- Cypriano S, Sousa MLR, Rihs LB, Wada RS. Saúde bucal dos préescolares, Piracicaba, Brasil, 1999. Rev Saúde Pública. 2003;37(2):24753.

11- Leite ICG, Ribeiro RA. Dental caries in the primary dentition in public nursey school children in Juiz de Fora, Minas Gerais, Brazil. Cad Saúde Pública. 2000;16(3):717-22.

12- Pinto, LMC. Avaliação da eficácia de um programa educativopreventivo na prevenção da cárie dentária. Dissertação de mestrado, Araçatuba: Faculdade de Odontologia, Universidade Estadual Paulista; 2000. 192p

13- Feitosa S, Colares V. Prevalência de cárie dentária em pré-escolares da rede pública de Recife, Pernambuco, Brasil, aos quatro anos de idade. Cad Saúde Pública. 2004;20(2):522-8.

14- Ueda EMO, Dezan CC, Frossard WTG, Salomão F, Morita MC Prevalence of dental caries in 3-year-old children living in a small Brazilian City. J Appl Oral Sci. 2004;12(1):34-8.

15- Bratthall D; Hansel-Petersson G; Sundberg H. Reasons for the caries decline: what do the experts believe? Eur J Oral Sci. 1996;104:416-22.

16- Tomita NE, Bijella VT, Lopes ES, Franco LJ. Prevalência de cárie dentária em crianças da faixa de 0 a 6 anos matriculadas em creches: importância de fatores socioeconômicos. Rev Saúde Pública. 1996;30(5):413-20.

17- Rong WS, Bian JY, Wang WJ, Wang JD. Effectiveness of an oral health education and caries prevention program in kindergartens in China. Community Dent Oral Epidemiol 2003;31(6):412-6.
18- World Health Organization. Infant and young child nutrition. Geneva: World Health Organization; 2002.

19- Honkala E, Myyssonen V, Rempela A. Determinants of frequency of children's sweets consumption. Acta Odontol Pediatr. 1984;5:139

20- Fraiz FC, Walter LRF. Study of the factors associated with dental caries in children who receive early dental care. Pesq Odontol Bras. 2001;15(3):201-7.

21- Tomita NE, Nadanovsky P, Vieira ALF, Lopes ES. Preferências por alimentos doces e cárie dentária em pré-escolares. Rev Saúde Pública. 1999;33(6):542-6. 